\title{
The Impact of Lifestyle, Brand Awareness, Product Quality, on Purchasing Decisions And Repurchase Intention Products for East Java \& Co
}

\author{
Julianti Fernanda Pasaribu', Joko Suyono², Damarsari Ratnasahara Elisabeth ${ }^{3}$ \\ julzfernanda@gmail.com ${ }^{1}$, joko.suyono@ narotama.ac.id $^{2}$ \\ Departement of Management, Faculty of Economic and Business, Narotama University, \\ Jl Arif Rahman Hakim No 51 Surabaya, Indonesia 60117., \\ ${ }^{3}$ Sekolah Tinggi Ilmu Ekonomi Mahardika, Department Of Management, Surabaya, Indonesia. ${ }^{3}$
}

\begin{abstract}
A large number of Indonesian people who live a healthy lifestyle makes organic agricultural products increasingly in demand because they have the best quality and health. Indonesia is a country that has a large population and is one of the countries that has an area of organic farming. Business people see the existence of organic food business opportunities to present products that are in line with market desires and stick to the hearts of consumers. Therefore, this study was prepared to analyze the impact of Lifestyle, Brand Awareness, and Product Quality on Purchasing Decisions and Repurchase Intention. This research is a quantitative research with a survey approach that uses a questionnaire of 100 respondents from consumers who buy organic products at the Surabaya Supermarket. The analysis technique used to prove the hypothesis is Partial Least Square (PLS). These results indicate that Lifestyle, Brand Awareness, Product Quality have a significant effect on Purchasing Decisions, and Purchasing Decisions have a significant effect on Repurchase Intention.
\end{abstract}

Keywords:Lifestyle, Brand Awareness, Product Quality, Purchasing Decisions, Repurchase Intention

\section{INTRODUCTION}

People begin to adopt healthy lifestyles, health aspects are important to avoid various disease threats. Not only adequate rest and regular exercise, but also maintaining consumption patterns by choosing healthy foods such as organic food. In research(Beharrell \& MacFie, 1991; Chinnici, Mario, \& Pecorino, 2002; Harper \& Makatouni, 2002; Hill \& Lynchehaun, 2002; Hutchins \& Greenhalgh, 1995; O’Donovan \& McCarthy, 2002; Pearson, 2001), revealing the reason consumers buy organic food is the consumer belief that organic food is healthier than inorganic food.

The Directorate General of Processing and Marketing of Agricultural Products (P2HP) said that the growth of the organic product market in Indonesia was quite rapid, resulting in an increase the number of farmers who manage organic farming from year to year. Also, there are increasing numbers of organic outlets in supermarkets and restaurants, and an increase in organic lover's organizations, as well as the existence of Lembaga Sertifikasi Organik atau LSM (ekonom.bisnis.com, 2015).

According to FIBL and IFOAM-Organics International in 2014, Indonesia recorded a ranking of 4 (four) of the largest areas of organic agriculture in Asia. Also Indonesia is ranked 4th with a population of 268,074,600. The high population and breadth of organic farming areas in Indonesia make it an opportunity for organic food businesses to bring organic products. 
Table 110 Country of Large Agricultural Area in Asia

\begin{tabular}{|l|c|c|}
\hline Countries & $\begin{array}{c}\text { Area of Agriculture } \\
\text { Organic (in thousand } \\
\text { hectares) }\end{array}$ & $\begin{array}{c}\text { The percentage of the total } \\
\text { agricultural area }\end{array}$ \\
\hline Tiongkok & 1.925 & $0.4 \%$ \\
India & 720 & $0.4 \%$ \\
Kazakhstan & 290.2 & $0.1 \%$ \\
Indonesia & 113.5 & $0.2 \%$ \\
Pilipina & 110.1 & $0.9 \%$ \\
Srilanka & 62.6 & $2.3 \%$ \\
Vietnam & 43.0 & $0.4 \%$ \\
Thailand & 37.7 & $0.2 \%$ \\
ArabSaudi & 37.6 & $0.1 \%$ \\
TimorLeste & 25.5 & $6.8 \%$ \\
\hline
\end{tabular}

Source : FIBL dan IFOAM-Organics International 2014

Many factors influence consumers to buy products. Environmental factors are a lifestyle, while from marketing factors there are prices, promotions, product quality, and brand awareness. Consumers can decide to buy if they already recognize the product to be purchased and seek information about the product. After evaluating and knowing the benefits of the product and according to their needs, a purchasing decision will be established. According to (Kotler dan Keller, 2009) decision is a problem-solving process that consists of problems, information, evaluation alternative, purchase decisions, and post-purchase behavior. Repurchase intention occurs when a person receives a positive response to past actions so that there is the reinforcement and can be accepted to enable individuals to make repeated purchases (Suryana \& Dasuki, 2013).

The focus of this research is organic products produced from natural ingredients and the best quality in each manufacture. This product is simple which is sourced directly from producers who apply organic farming and natural ingredients in collaboration with farmers.

\section{LITERATURE REVIEW}

\section{Lifestyle (X1)}

Lifestyle is the desire of every person to achieve the needs of his interest, environmental factors and the development of the times make someone's desire to change. A person can be assessed for his lifestyle from habits, for example when wearing clothes, food consumed, and activities are undertaken. Lifestyle can be assessed positively or negatively, depending on people's judgment. An example of a positive lifestyle is with adequate rest, exercise, consuming healthy foods, and of course good activities. Whereas a negative lifestyle is the opposite of a positive lifestyle that is by doing inappropriate things that lead to a bad view of people.

This research explores the influence of Lifestyle variables on Purchasing Decisions and Interests to repurchase, using lifestyle indicators proposed by Sunarto in (Mandey, 2009), namely: activities, interests, and opinions.

Hypothesis 1: Lifestyle has a significant effect on purchasing decisions. The higher the consumer lifestyle, the higher the level of consumer purchasing decisions.

\section{Brand Awareness (X2)}

Brand awareness is one component that can influence purchasing decisions because consumers can remember a product simply by being given the product code. According to (Hoeffler \& Keller, 2002) indicate that brand awareness can be distinguished from depth and width. Depth means how to form consumers can recognize brands easily when expressing and concluding when consumers buy products, brand names will immediately appear in their minds.

This research explores the effect of Brand Awareness variable or brand awareness on Purchase Decisions and Interests to repurchase, by using brand awareness indicators proposed by (Yoo, Donthu, \& Lee, 2000) there are 6 indicators of brand awareness, namely:

1. I know how the product looks $\mathrm{X}$

2. I can recognize $X$ products among other competing brands

3. I am aware of product $\mathrm{X}$ 
4. some of the characteristics of X products appear in my mind quickly

5. I can quickly remember product $X$ symbol or logo

6. I have difficulty in imagining product $X$ in my mind. ( $r$ )

Hypothesis 2: Brand awareness has a significant effect on purchasing decisions. The more and complete brand awareness available to consumers, the higher the level of consumer purchasing decisions will be.

\section{Product Quality (X3)}

Product quality is the ability of a product to demonstrate its function, this includes overall durability, reliability, accuracy, ease of operation, and product repairs as well as other product attributes (Kotler \& Keller, 2012). Whereas according to (Wijaya, 2011) Product quality is an overall combination of product characteristics resulting from marketing, production engineering, and maintenance that make the product can be used to meet customer or consumer expectations.

This study explores the effect of Product Quality variables or product quality on Purchasing and Purchasing Decision Interests, using product quality indicators proposed by Sviokla in Lupiyoadi revealed (2013: 214) that there are eight indicators, namely:

1. Performance

2. Characteristics or additional features

3. Reliability

4. conformance to specifications

5. durability

6. serviceability

7. aesthetics

8. perceived quality.

Hypothesis 3: Product quality has a significant effect on customer satisfaction. The better the quality of products that are given to consumers according to their needs and desires. The higher the level of purchasing decisions.

\section{Purchasing Decisions (Y1)}

According to (Setiadi, 2010) buying behavior implies that the activities of individuals are directly involved in the exchange of money with goods and services and the decision-making process. Whereas (Kotler $\&$ Keller, n.d.) argues that in the evaluation phase consumers form preferences for brands that are in a collection of choices. In some cases, consumers can make a decision not to formally evaluate each brand. According to (Kotler \& Armstrong, 2013), the buyer decision process consists of five stages:

1. introduction to needs

2. information seeking

3. evaluation of alternatives

4. purchasing decisions

5. post-purchase behavior.

Hypothesis 4: Purchasing decisions have a significant effect on customer satisfaction. The more consumers who decide to consume and buy organic products, there will be interest in repurchasing after the first purchase.

\section{Repurchase Intention (Y2)}

According to Sukmawati and Suyono in Pramono taken from Annafik and Rahardjo (2012), buying interest is part of the component of behavior in consuming. The interest in buying consumers is the stage where consumers form their choices among several brands incorporated in the chosen device. Then, in the end, purchase an alternative that he likes most of the process that consumers go through to buy an item or service based on various considerations.

According to (Lu, Chang, \& Chang, 2014), there are five factors that influence consumer buying interest, among others:

1. I would consider buying this product

2. I have no intention to buy this product

3. It is possible that I would buy this product

4. I will purchase (brand) the next time I need a product

5. If I am in need

6. I would buy this (product). 


\section{Framework For Concepts}

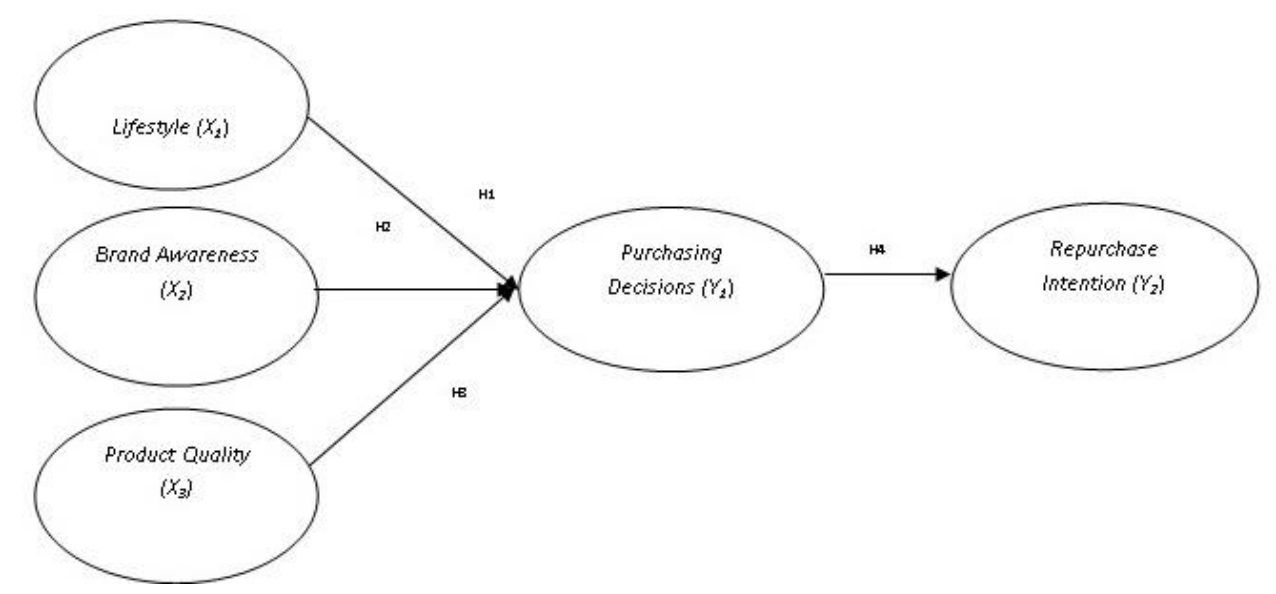

Figure 1: Research Model

H1 : Lifestyle has a significant effect on purchasing decisions.

$\mathrm{H} 2$ : Brand awareness has a significant effect on purchasing decisions.

H3 : Product quality has a significant effect on purchasing decisions.

H4 : Purchasing decisions has a significant effect on repurchase intention.

\section{METHODS}

\section{Research Approach}

Research uses a quantitative approach is as stated by (Sugiyono, 2006) that is a research method that is based on the philosophy of positivism, which is used to examine a particular population or sample, sampling techniques carried out randomly, data collection using research instruments, quantitative data analysis with the aim of testing the predetermined hypothesis.

\section{Data Types}

The type of data used in this study is the data collection method because it collects information data using an online questionnaire distributed to consumers in The Gourmet Galaxy that buys organic research products.

\section{Population}

The population is a collection or group of people or objects that have certain similarities chosen by researchers to be studied and conclusions can be drawn (Sugiyono, 2006). In this study, the population is 140 consumers who buy organic products.

\section{Sample}

The sample is a portion of the population that is considered that its characteristics can represent the population (Sugiyono, 2014). The method in this study uses probability sampling with a technique that is a sampling technique that gives equal opportunity to each member of the population to be chosen as a member of the sample regardless of the level that exists in the population. The number of samples using the Isaac and Michael tables is $5 \%$ significance which is equal to 100 respondents.

\section{Data Analysis}

According to the analysis model used for this study, namely the Structural Equation Model (SEM), the exogenous variables, indicators ( measured variables / observed variables), and endogenous (Ferdinand, 2000).

\section{RESULTS AND DISCUSSION}

\section{Analysis of Structural Equation Model (SEM) Data with Partial Least Square.}




\section{Evaluation of Outer Models Discrimant Validity}

To measure discriminant validity, cross loading values can be used. An indicator is said to fulfill discriminant validity if the value of the cross loading indicator for the variable is the largest compared to other variables (Hair et al., 2014). The value of cross loading in this study is presented in the table below:

Table 2 : Discriminant Validity

\begin{tabular}{|c|c|c|c|c|c|}
\hline & $\begin{array}{l}\text { Lifestyle } \\
\text { X1 }\end{array}$ & Brand Awareness X2 & $\begin{array}{l}\text { Quality Product } \\
\text { X3 }\end{array}$ & $\begin{array}{c}\text { Purchasing Decisions } \\
\text { Y1 }\end{array}$ & Repurchase Intention Y2 \\
\hline $\mathrm{X} 1.1$ & 0.836 & 0.566 & 0.732 & 0.706 & 0.595 \\
\hline $\mathrm{X} 1.2$ & 0.810 & 0.651 & 0.579 & 0.646 & 0.505 \\
\hline $\mathrm{X} 1.3$ & 0.931 & 0.713 & 0.815 & 0.932 & 0.608 \\
\hline $\mathrm{X} 2.1$ & 0.676 & 0.838 & 0.724 & 0.691 & 0.485 \\
\hline $\mathrm{X} 2.2$ & 0.575 & 0.802 & 0.633 & 0.632 & 0.443 \\
\hline $\mathrm{X} 2.3$ & 0.551 & 0.790 & 0.638 & 0.589 & 0.472 \\
\hline $\mathrm{X} 2.4$ & 0.678 & 0.870 & 0.707 & 0.724 & 0.552 \\
\hline $\mathrm{X} 2.5$ & 0.643 & 0.822 & 0.716 & 0.750 & 0.582 \\
\hline $\mathrm{X} 2.6$ & 0.288 & 0.515 & 0.324 & 0.320 & 0.350 \\
\hline $\mathrm{X} 3.1$ & 0.697 & 0.694 & 0.821 & 0.750 & 0.495 \\
\hline $\mathrm{X} 3.2$ & 0.620 & 0.643 & 0.800 & 0.703 & 0.651 \\
\hline X3.3 & 0.662 & 0.619 & 0.845 & 0.718 & 0.610 \\
\hline X3.4 & 0.717 & 0.710 & 0.840 & 0.702 & 0.663 \\
\hline $\mathrm{X} 3.5$ & 0.720 & 0.564 & 0.797 & 0.729 & 0.635 \\
\hline X3.6 & 0.664 & 0.523 & 0.656 & 0.692 & 0.517 \\
\hline X3.7 & 0.535 & 0.713 & 0.730 & 0.559 & 0.530 \\
\hline X3.8 & 0.514 & 0.660 & 0.705 & 0.532 & 0.495 \\
\hline Y1.1 & 0.813 & 0.676 & 0.789 & 0.901 & 0.589 \\
\hline Y1.2 & 0.922 & 0.732 & 0.793 & 0.926 & 0.594 \\
\hline Y1.3 & 0.649 & 0.813 & 0.722 & 0.778 & 0.618 \\
\hline Y1.4 & 0.765 & 0.645 & 0.765 & 0.897 & 0.686 \\
\hline Y2.1 & 0.404 & 0.296 & 0.447 & 0.363 & 0.780 \\
\hline Y2.2 & 0.408 & 0.304 & 0.435 & 0.374 & 0.786 \\
\hline Y 2.3 & 0.682 & 0.700 & 0.779 & 0.791 & $\mathbf{0 . 8 3 7}$ \\
\hline Y2.4 & 0.395 & 0.397 & 0.436 & 0.420 & 0.657 \\
\hline
\end{tabular}

Source: Attachment, processed

Based on data from table 2 it can be seen that some values of loading factors for each indicator from each construct have a greater value than the others. This shows that latent variables have a size on their block better than others.

\section{Reability}

To measure a variable has Composite Reliabilty, which is good in the indicator group can be seen from the value of Composite Reability $\geq 0.7$ (Hair et al., 2014). The Composite Reliability value can be seen in the following table:

Table 3: Reability and AVE 


\begin{tabular}{|l|c|c|}
\hline & Composite Reliability & Average variance Extracted (AVE) \\
\hline Lifestyle (X1) & 0.895 & 0.740 \\
Brand Awareness (X2) & 0.902 & 0.611 \\
Product Quality (X3) & 0.924 & 0.604 \\
Purchasing Decisions (Y1) & 0.930 & 0.770 \\
Repurchase Intention (Y2) & 0.851 & 0.590 \\
\hline
\end{tabular}

Source: Attachment, processed

Based on table 3, it can be seen that all variables have met the Composite Reliability criteria. This is indicated by the value of Composite Reliability above 0.70 and AVE above 0.50 so that all constructs form a good model.

\section{Inner Model Evaluation \\ R-Squared Value}

In assessing the model using PLS it starts by looking at the R-square adjusted for each dependent latent variable. Table 4.13 below is the result obtained from the adjusted R-square estimation using SmartPLS 3 software.

Table 4 : R-Squared Value

\begin{tabular}{|l|l|}
\hline Variabel & R-square Adjusted \\
\hline Purchasing Decisions $(Y 1)$ & 0.870 \\
Repurchase Intention $(Y 2)$ & 0.497 \\
\hline
\end{tabular}

Source: Attachment, processed

The R-Adjusted variable Purchasing Decisions results show that the Lifestyle, Brand Awareness, Product Quality variables contribute $87 \%$ to purchasing decisions and the remaining 23\% is influenced by other factors, while the Repurchase Intention R-Adjusted variable is 0.497 . These results indicate that Lifestyle variables, Brand Awareness, Product Quality contributes $49.7 \%$ and the remaining $50.3 \%$ is influenced by other factors.

\section{Hypothesis testing}

Testing the hypothesis in this study was carried out using Bootstrapping Testing. After bootstrapping the testing process and the output results obtained are as follows:

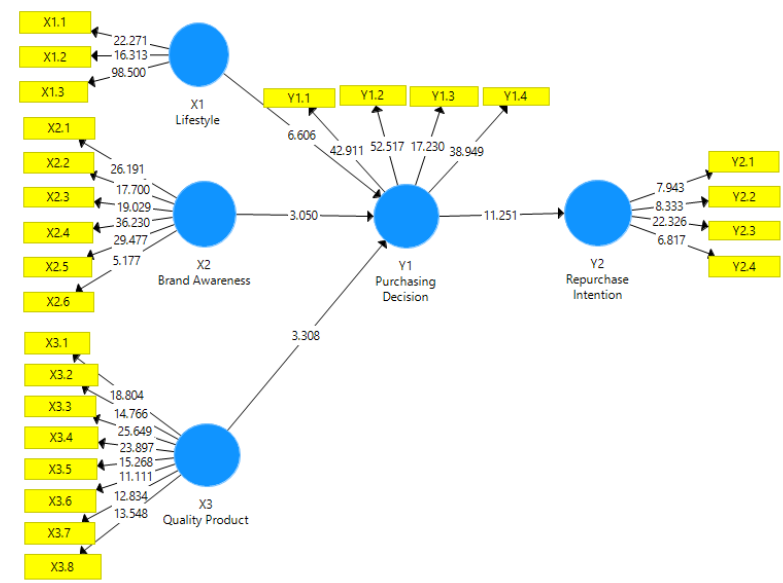

Figure 1

Results Path Diagram After Bootstrapping Analysis 
The criteria in acceptance or rejection of the hypothesis are that $\mathrm{HI}$ is accepted if the t-statistic shows a value greater than the value of t-table that is equal to 1.661 and if the $p$-value is less than 0.05 . If it does not meet these criteria, Ho is rejected.

\section{Direct and indirect effect results}

In testing the hypothesis, a data must meet a criterion, and the hypothesis is said to be accepted if the $\mathrm{t}$ statistic value is greater than t-table and if the p-value is less than 0.05 and vice versa.

The output of the PLS-SEM as follows:

Tabel 5 : Path Coefficient

\begin{tabular}{|l|l|l|}
\hline \multicolumn{1}{|c|}{ Path Coefficient } & t-statistic & $\boldsymbol{p}$-value \\
\hline Lifestyle (X1) ->Purchasing Decisions (Y1) & 6.606 & 0.003 \\
Brand Awareness (X2) ->Purchasing Decisions (Y1) & 3.050 & 0.001 \\
Product Quality (X3) ->Purchasing Decisions (Y1) & 3.308 & 0.001 \\
Purchasing Decisions (Y1) ->Repurchase Intention (Y2) & 11.251 & 0.000 \\
Lifestyle $\rightarrow$ Purchasing Decisions $\rightarrow$ Repurchase Intention & 6.081 & 0.000 \\
Brand Awareness $\rightarrow$ Purchasing Decisions $\rightarrow$ Repurchase Intention & 2.935 & 0.002 \\
Product Quality $\rightarrow$ Purchasing Decisions $\rightarrow$ Repurchase Intention) & 2.865 & 0.002 \\
\hline
\end{tabular}

Source: Attachment, processed

\section{Direct influence}

Hypothesis 1: Lifestyle Influence on Purchasing Decisions

Variable Lifestyle (X1) has a significant effect on Purchasing Decisions (Y1) because the value of tcount is greater than the value of t-table 1.661 which is equal to 6.606 and the p-Value value is less than 0.05 which is 0.003 .

The results of this study are supported by previous research conducted (Tarigan, 2016) which states Lifestyle (Lifestyle) has a positive and significant effect on purchasing decisions. This shows that consumers who follow a healthy lifestyle will maintain their dietary patterns by consuming healthy foods that are organic.

Hypothesis 2: Effect of Brand Awareness on Purchasing Decisions

Based on the results of the analysis, it can be seen that the Brand Awarenesss (X2) variable has a significant effect on Purchasing Decisions (Y1) because the calculated t-value is greater than the t-table of 1.661 which is 3.050 and the p-vaiue value is less than 0.05 , which is 0.001 .

This research is supported by previous research conducted by (Eris Dwiyanti, 2018) which states the positive and significant relationship between Brand Awareness of purchasing decisions. This shows that it is different and classy, there is also an organic writing on the packaging that makes these organic products can be remembered by consumers and easily known.

Hypothesis 3: Effect of Product Quality on Purchasing Decisions

Based on the results of the analysis, it can be seen that the Product Quality (X3) variable has a significant effect on Purchasing Decisions (Y1) because the t-statiatic value is greater than the t-table of 1.661, which is 3.308 and the value of less than 0.05 is 0.001 .

This research is supported by previous research conducted (Widyastuti, 2018) saying that purchasing decisions are influenced by Quality and Price. This shows that the better the quality of the product given to consumers in accordance with their needs and desires, the higher the level of decision to purchase organic products.

Hypothesis 4 : Effects of Purchasing Decisions on Repurchase Intention

Based on the results of the analysis conducted using smartPLS, it can be concluded that the Purchasing Decisions variable has a positive and significant effect on Repurchase Intention. This can be seen from the pvalue of 0.000 which is less than 0.050 and the $t$-statistic value is 11.251 which is more than the t-table value of 1.661. With this, the H1 hypothesis in this study was accepted. 
This research is supported by previous research conducted by (Suyana \& Dasuki, 2013) that purchasing decisions affect consumers' buying interest. This shows that with consumers who decide to purchase organic products.

\section{Indirect Effects}

Lifestyle (X1) against Repurchase Intention (Y2) through Purchasing Decisions (Y1)

Based on the results of the analysis carried out using SmartPLS, it can be concluded that Variable Lifestyle (X1) has a positive and significant indirect effect on Repurchase Intention (Y2) through Purchasing Decisions (Y1). This can be seen from the p-value of 0.000 which is less than 0.05 and the t-statistic value of 6.081 which is more than the t-table value of 1.661. this shows consumers who adopt a healthy lifestyle will decide to repurchase the desired product.

\section{Brand Awareness (X2) towards Repurchase Intention (Y2) Through Purchasing Decisions (Y1)}

Based on the results of the analysis carried out using SmartPLS, it can be concluded that Brand Awareness Variable (X2) indirectly and significantly affects Repurchase Intention (Y2) through Purchasing Decision (Y2). This can be seen from the p-value of 0.002 which is less than 0.05 and the t-statistic value is equal to 2,935 which is more than the t-table value of 1,661. this shows consumers who recognize and know the benefits of East Java \& Co products will decide to buy the desired product again.

\section{Product Quality (X3) against Reurchase Intention (Y2) Through Purchasing Decisions (Y1)}

Based on the results of the analysis carried out using SmartPLS, it can be concluded that the Product Quality Variable (X3) indirectly positively and significantly affects Repurchase Intention (Y2) through Purchasing Decision (Y2). This can be seen from the p-value of 0.002 which is less than 0.05 and the t-statistic value of 2.865 which is more than the t-table value of 1,661. this shows consumers with good quality products and providing benefits to consumers will decide to repurchase organic products.

\section{CONCLUSION}

The findings of this study indicate:

1. There is a positive and significant influence between Lifestyle variables on Purchasing Decisions. based on the results of processing the data it can be concluded that consumers who follow a healthy lifestyle decide to buy organic food products.

2. There is a positive and significant influence between the variable Brand Awareness of Purchasing Decisions. Based on the results of data processing it can be concluded that the presence of Brand Awareness is very influential in purchasing decisions due to the appearance of different products from its competitors, there are also organic writing on the packaging that makes the product easy for consumers to remember.

3. There is a positive and significant influence between Product Quality variables on Purchasing Decisions. Based on the results of data processing, it can be concluded that the better the quality of the product given to consumers in accordance with their needs and desires, the higher the level of decision to make product purchases.

4. There is a positive and significant influence between the Purchasing Decision variable on Repurchase Intention. Based on the results of processing the data it can be concluded that the existence of a Purchasing Decision is taken into consideration so as to encourage consumers to buy products again.

\section{REFERENCES}

Arikunto, S. (2002). Prosedur Penelitian. Jakarta : Rineka Cipta. Prosedur Penelitian. Jakarta : Rineka Cipta. Bakar, A. (2010). Analisis Perbandingan Kinerja Perusahaan Telekomunikasi Dengan Menggunakan Eva, Reva, Fva, Dan Mva. Jurnal Rekayasa Institut Teknologi Nasional.Lppm Itenas, X Iv, 19-27.

Bastian, I. (2006). Akuntansi Sektor Publik: Suatu Pengantar. Jakarta: Erlangga.

Brigham, H. Dan. (2001). Manajemen Keuangan. (8th Ed.). Jakarta: Erlangga.

Butarbutar, L. (2017). Analisis Kinerja Keuangan Menggunakan Pendekatan Economic Value Added (Eva) Dan Market Value Added (Mva) Pada Perusahaan Bumn Sektor Pertambangan Yang Terdaftar Di Bei Periode 2011-2015.

Fauzan, M. S. (2012). Analisis Kinerja Keuangan Dengan Menggunakan Metode Eva (Economic Value Added) Pada Pt. Raja Tirta Jaya Di Makassar. Skripsi. Fakultas Ekonomi Dan Bisnis Universitas Hasanuddin.

Harahap, S. S. (2001). Analisa Kritis Atas Laporan Keuangan (Edisi Satu). Jakarta : Pt Raja Grafindo Persada. Hoeffler, S., \& Keller, K. L. (2002). Building brand equity through corporate societal marketing. Journal of 
Public Policy \& Marketing, 21(1), 78-89.

Kim, W. G. (2006). Eva And Traditional Accounting Measures: Which Metric Is A Better Predictor Of Market Value Of Hospitality Companies?

Luh Putu Ayu Purnami, F. Y., \& Yulianthini, N. N. (2016). Kinerja Keuangan Menggunakan Pendekatan Economic Value Added (Eva) Dan Market Value Added (Mva) Pada Bank Bumn.

Lupiyoadi, Rambat dan A.Hamdani. 2006. Manajemen Pemasaran Jasa Edisi 2. Jakarta: Salemba Empat

Maheni Ika Sari, B. W. (2018). Mengukur Kinerja Keuangan Dengan Eva Dan Mva.

Muhammad Ridho Firdausi, Dadan Rahadian, A. S. D. (2017). Analisis Kinerja Keuangan Dengan Menggunakan Metode Economic Value Added (Eva), Financial Value Added (Fva) Dan Market Value Added (Mva) Studi Kasus Pada Operator Telekomunikasi Yang Terdaftar Di Bei Periode 2008-2015.

Muis, P. Dan. (2009). Metodologi Ekonomi Dan Bisnis. Yogyakarta: Graha Ilmu.

O’byrne, Y. \&. (2001). Eva Dan Manajemen Berdasarkan Nilai (1st Ed.). Jakarta: Salemba Empat.

Okaberina Pratiwi, U. (2017). Analisis Kinerja Keuangan Perusahaan Pulp Dan Kertas Yang Go Public Di Bursa Efek Indonesia (Bei) Berdasarkan Metode Economic Value Added (Eva), Market Value Added (Mva) Dan Return On Asset (Roa) Periode 2011-2015.

Saeid Jabbarzadeh Kangarloei , Morteza Motavassel, E. A. And B. S. (2012). The Investigation Of The Relationship Between Economic Value Added (Eva) And Return On Assets (Roa) In Tehran Stock Exchange (Tse).

Sartono, A. (2001). Manajemen Keuangan Teori Dan Aplikasi. Yogyakarta: Agus Sartono, 2001. Manajemen Keuangan Teori Dan Aplikasi. Yogyakarta: Bpef-Yogyakarta.

Sharma, A. K. (2012). Eva Versus Convenational Performance Measures - Empirical Evidence From India.

Tunggal. (2008a). Analisis Penilaian Kinerja Keuangan Menggunakan Penerapan Economic Value Added.

Tunggal, A. W. (2008b). Dasar-Dasar Customer Relationship Management (Crm). Jakarta: Harvindo.

Van Horne, J. C. And J. M. W. (2007). Fundamentals Of Financial Management, Prinsip-Prinsip Manajemen Keuangan. Jakarta: Salemba Empat.

Wet, J. H. Vh. De. (2012). Executive Compensation And The Eva And Mva Performance Of South African Listed Companies.

Wet, Jh. De. (2005). Eva Versus Traditional Accounting Measures Of Performance As Drivers Of Shareholder Value - A Comparative Analysis.

Willer, H, Lernoud, J, (2014) The World of Organic Agriculture. Statistics and Emerging

Trends 2015. FiBL, Frick, and, IFOAM - Organics International, Bonn

Winarto. (2010). Tagetes Berguna Bagi Kita. Deptan. Sumatera Utara: Bptp.

Wiweko, H. (2014). Penilaian Kinerja Keuangan Perusahaan Dengan Metode Rasio Keuangan, Economic Value Added (Eva) Dan Market Value Added (Mva) (Studi Kasus : Sektor Farmasi Di Bursa Efek Indonesia), $11,86-100$. 